Note

\title{
Structure of Rosellichalasin, a New Metabolite Produced by Rosellinia necatrix
}

\author{
Yasuo Kimura, Hiromitsu NaKaJima \\ and Takashi HAMASAKI
}

\author{
Department of Agricultural Chemistry, \\ Tottori Universty, Koyama, \\ Tottori 680, Japan
}

Received Octobef 7, 1988

Rosellinia necatrix is a pathogenic fungus which causes white root rot to potato, soybean, tea, peanut, apple and so on. ${ }^{11}$ It is well known that this fungus produces cytochalasin $\mathbf{E},{ }^{2)}$ which has physiological activity towards mammalian cells, ${ }^{31}$ microorganisms ${ }^{43}$ and plants. ${ }^{4,5)}$

We have searched in detail for new plant growth regulators in the metabolites of this fungus and succeeded in isolating of the compound designated rosellichalasin (1) together with cytochalasin $\mathrm{E}(\boldsymbol{2})$. This paper deals with the isolation and structural elucidation of rosellichalasin.

This fungus, Rosellinia necatrix, was statically cultured in a malt extract medium ( 401 ) containing $3 \%$ of peptone at $24^{\circ} \mathrm{C}$ for 21 days. Dry mycelial mats were obtained by filtering the broth and repeatedly extracted with acetone. The acetone extract $(5 \mathrm{~g}$ ) was purified by a silica gel column with a solvent system of benzene-acetone. The eluate with a benzene-acetone ratio of $9: 1(\mathrm{v} / \mathrm{v})$ was evaporated, and the residual solid was crystallized from $n$ hexane-ethyl acetate to afford colorless needles of 1 (78 mg). The eluate with a benzene-acetone mixture of $4: 1$ $(\mathrm{v} / \mathrm{v})$ was concentrated in vacuo, and the residue was applied to a Sephadex LH-20 column eluted with meth-

1

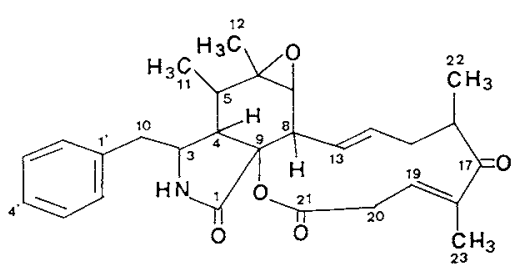

2

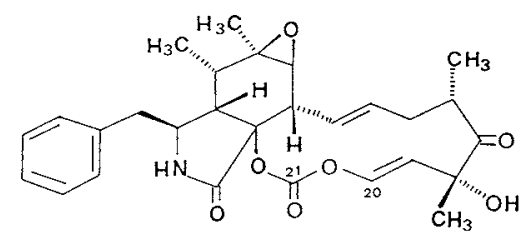

anol. The white amorphous compound thus obtained was crystallized from $n$-hexane-acetone to give colorless needles of 2 ( $1.48 \mathrm{~g})$.

The molecular formula of 2 , showing $\mathrm{mp} 205 \sim 206^{\circ} \mathrm{C}$ and $[\alpha]_{\mathrm{D}}^{20}-20^{\circ}(c=1.0, \mathrm{MeOH})$, was determined to be $\mathrm{C}_{28} \mathrm{H}_{33} \mathrm{NO}_{7}$ by EIMS ( ${ }^{+}, m / z$ 495) and elementary analysis (Found: $\mathrm{C}, 67.8 ; \mathrm{H}, 6.85 ; \mathrm{N}, 2.59$. Calcd.; $\mathrm{C}$, $67.86 ; \mathrm{H}, 6.71 ; \mathrm{N}, 2.83 \%$ ). The UV, IR, NMR and mass spectra together with $[\alpha]_{\mathrm{D}}$ revealed 2 to be cytochalasin $\mathrm{E}^{6}{ }^{6}$ All the proton signals of 2 were assigned by decoupling experiments and literature values ${ }^{7,8}$ to be those shown in the table.

Compound 1 was recrystallized from $n$-hexane-actone to afford colorless needles, mp $121 \sim 123^{\circ} \mathrm{C}$ and $[\alpha]_{\mathrm{D}}^{20}$ $-2.7^{\circ}(c=1.0, \mathrm{MeOH})$. The molecular formula was determined to be $\mathrm{C}_{28} \mathrm{H}_{33} \mathrm{NO}_{5}$ by HRMS (found, 463.2343; calcd., 463.2356).

The IR absorption bands at 1665 and $1640 \mathrm{~cm}^{-1}$ together with the UV absorption band at $245 \mathrm{~nm}(\varepsilon=12,500$ in $\mathrm{EtOH}$ ) indicated the presence of an $\alpha, \beta$-unsaturated ketone. $^{9 \text { ) }}$

Mass spectral analysis by EIMS for 1 gave a molecular ion peak at $m / z 463$, with fragment ion peaks at $m / z 372$, 190,120 and 91 (base peak). The fragment ion peak at 372 $\left(\mathrm{M}^{+}-91\right)$ is expected to have been derived from the molecular ion peak by the loss of a benzyl ion $(\mathrm{m} / z \mathrm{~g} 1)$. That the benzyl group is part of a phenethylamine system is indicated by the presence of an $\mathrm{C}_{8} \mathrm{H}_{10} \mathrm{~N}^{+}(\mathrm{m} / \mathrm{z} 120)$ ion in the mass spectrum. The presence of intense peak at $m / z$ 190 corresponding to $\mathrm{C}_{11} \mathrm{H}_{12} \mathrm{NO}_{2}{ }^{+}$must contain the elements of the lactam ring and the benzyl groups. ${ }^{10}$ ) These results together with the subsequent physicochemical properties described suggest that 1 was a cytochalasin analog.

A comparison of the ${ }^{13} \mathrm{C}-\mathrm{NMR}$ spectral data between 1 and 2 indicates that the carbonate carbon at $\delta_{\mathrm{C}} 149.3(\mathrm{C}$ 21 ) in 2 was shifted downfield to $\delta_{\mathrm{C}} 171.8(\mathrm{C}-21)$ in $\mathbf{1}$, which was assigned to an ester carbon. This result is well consistent with that of the IR spectrum $\left(v_{\mathrm{c}=0}, 1718 \mathrm{~cm}^{-1}\right)$, in which no absorption band at $1765 \mathrm{~cm}^{-1}$ in 2 due to a carbonate ${ }^{11)}$ was observed in $\mathbf{1}$.

The signal at $\delta_{\mathrm{H}} 6.35(1 \mathrm{H}, \mathrm{dd}, J=6.8,11.0 \mathrm{~Hz})$ assignable to a vinyl proton attached to a carbon at $\delta_{\mathrm{C}} 135.1(\mathrm{C}$ 19) exhibited couplings with the methylene protons at $\delta_{\mathrm{H}}$ $2.98(1 \mathrm{H}, \mathrm{dd}, J=6.8,12.1 \mathrm{~Hz})$ and $3.23(1 \mathrm{H}$, dd, $J=11.0$, $12.1 \mathrm{~Hz}$ ) attached to a carbon at $\delta_{\mathrm{C}} 39.8(\mathrm{C}-20)$. Also, irradiation of the signal at $\delta_{\mathrm{H}} 6.35$ sharpened the signal at $\delta_{\mathrm{H}} 1.83\left(3 \mathrm{H}\right.$, br. s) connected to a carbon at $\delta_{\mathrm{C}} 12.8(\mathrm{C}-23)$, indicating a long-range allylic coupling between the meth$\mathrm{yl}$ and vinyl protons.

The methyl carbon at $\delta_{\mathrm{C}} 12.8$ (C-23) indicates the connection with a $\mathrm{C}-18$ carbon at $\delta_{\mathrm{C}} 143.1$ (s) in 1 due to a $\mathrm{sp}^{2}$ carbon appearing instead of the signal at $\delta_{\mathrm{C}} 76.7(\mathrm{~s}, \mathrm{C}$ 18) in 2. These results prove the presence of the partial structure $-\mathrm{CH}_{2}-\mathrm{CH}=\mathrm{C}\left(\mathrm{CH}_{3}\right)-$ in 1 . The double bond was shown to be trans, since the coupling constant between the methyl protons at $\delta_{\mathrm{H}} 1.83$ and the proton at $\delta_{\mathrm{H}} 6.35$ was 
Table. ${ }^{1} \mathrm{H}$ - AND ${ }^{13} \mathrm{C}-\mathrm{NMR}$ Data FOR 1 And 2 , AND ${ }^{13} \mathrm{C}$-NMR Data for CYTOChalasin E $\left(\mathrm{H}, 270 \mathrm{MHz} ; \mathrm{C}, 68 \mathrm{MHz} ; \mathrm{CDCl}_{3}\right)$

\begin{tabular}{|c|c|c|c|c|c|}
\hline \multirow{2}{*}{$\begin{array}{l}\text { Carbon } \\
\text { number }\end{array}$} & \multicolumn{2}{|r|}{ Compound 1} & \multicolumn{2}{|r|}{ Compound 2} & \multirow{2}{*}{$\frac{\text { Cytochalasin } \mathrm{E}^{14}}{\delta_{\mathrm{C}}{ }^{a}}$} \\
\hline & $\delta_{\mathrm{C}}$ & $\delta_{\mathrm{H}}$ & $\delta_{\mathrm{C}}$ & $\delta_{\mathrm{H}}$ & \\
\hline 11 & $12.4 \mathrm{q}$ & $1.00 \mathrm{~d}(7.3)^{a}$ & $13.1 \mathrm{q}$ & $1.09 \mathrm{~d}(7.3)$ & $13.1 \mathrm{q}$ \\
\hline 22 & $17.4 \mathrm{q}$ & $1.13 \mathrm{~d}(6.8)$ & $19.6 \mathrm{q}$ & $1.16 \mathrm{~d}(6.3)$ & $19.6 q$ \\
\hline 12 & $19.6 \mathrm{q}$ & $1.23 \mathrm{~s}$ & $20.0 q$ & $1.26 \mathrm{~s}$ & $20.1 \mathrm{q}$ \\
\hline 23 & $12.8 \mathrm{q}$ & $1.83 \mathrm{br} . \mathrm{s}$ & $24.3 q$ & $1.48 \mathrm{~s}$ & $24.4 \mathrm{q}$ \\
\hline 5 & $36.0 \mathrm{~d}$ & $2.23 \mathrm{dq}(5.4,7.3)$ & $35.8 \mathrm{~d}$ & $2.28 \mathrm{dq}(4.9,7.3)$ & $35.9 \mathrm{~d}$ \\
\hline \multirow[t]{2}{*}{15} & $36.6 \mathrm{t}$ & $2.03 \mathrm{~m}$ & $39.1 \mathrm{t}$ & $2.15 \mathrm{ddd}(2.2,3.8,12.7)$ & $39.2 \mathrm{t}$ \\
\hline & & $2.24 \mathrm{~m}$ & & $2.67 \mathrm{~m}$ & \\
\hline 16 & $39.8 \mathrm{~d}$ & $3.27 \mathrm{~m}$ & $40.8 \mathrm{~d}$ & $2.93 \mathrm{~m}$ & $40.8 \mathrm{~d}$ \\
\hline \multirow[t]{2}{*}{10} & $44.1 \mathrm{t}$ & $2.85 \mathrm{~d}(2 \mathrm{H}, 5.4)$ & $44.7 \mathrm{t}$ & $2.70 \mathrm{dd}(6.8,13.1)$ & $44.2 \mathrm{t}$ \\
\hline & & & & $2.90 \mathrm{dd}(4.4,13.1)$ & \\
\hline 4 & $48.8 \mathrm{~d}$ & $2.72 \mathrm{dd}(2.0,5.4)$ & $47.8 \mathrm{~d}$ & $3.03 \mathrm{dd}(2.9,4.9)$ & $47.2 \mathrm{~d}$ \\
\hline 8 & $47.0 \mathrm{~d}$ & $2.86 \mathrm{dd}(5.4,10.3)$ & $45.8 \mathrm{~d}$ & $2.63 \mathrm{~m}$ & $45.8 \mathrm{~d}$ \\
\hline 3 & $53.9 \mathrm{~d}$ & $3.73 \mathrm{~m}$ & $53.7 \mathrm{~d}$ & $3.74 \mathrm{~m}$ & $53.7 \mathrm{~d}$ \\
\hline 6 & $57.2 \mathrm{~s}$ & & $57.3 \mathrm{~s}$ & & $57.4 \mathrm{~s}$ \\
\hline 7 & $60.3 d$ & $2.67 \mathrm{~d}(5.4)$ & $60.6 \mathrm{~d}$ & 2.63 & $60.7 \mathrm{~d}$ \\
\hline 18 & $143.1 \mathrm{~s}$ & & $76.7 \mathrm{~s}$ & & $76.7 \mathrm{~s}$ \\
\hline 9 & $84.7 \mathrm{~s}$ & & $87.0 \mathrm{~s}$ & & $87.4 \mathrm{~s}$ \\
\hline 19 & $135.1 \mathrm{~d}$ & 6.35 br.dd $(6.8,11.0)$ & $120.3 \mathrm{~d}$ & $5.63 \mathrm{~d}(11.7)$ & $120.3 \mathrm{~d}$ \\
\hline $4^{\prime}$ & $125.7 \mathrm{~d}$ & $7.28 \mathrm{~m}$ & $127.3 \mathrm{~d}$ & $7.30 \mathrm{~m}$ & $127.2 \mathrm{~d}$ \\
\hline 13 & $127.1 \mathrm{~d}$ & $5.83 \mathrm{ddd}(1.5,10.3,15.1)$ & $128.4 \mathrm{~d}$ & $5.89 \mathrm{ddd}(1.6,8.3,16.0)$ & $128.7 \mathrm{~d}$ \\
\hline $3^{\prime}, 5^{\prime}$ & $128.8 \mathrm{dd}$ & $7.28 \mathrm{~m}$ & $128.9 \mathrm{dd}$ & $7.30 \mathrm{~m}$ & $128.8 \mathrm{dd}$ \\
\hline $2^{\prime}, 6^{\prime}$ & $129.6 \mathrm{dd}$ & $7.28 \mathrm{~m}$ & $129.6 \mathrm{dd}$ & $7.30 \mathrm{~m}$ & $129.9 \mathrm{dd}$ \\
\hline 14 & $131.8 \mathrm{~d}$ & 5.44 ddd $(3.9,11.2,15.1)$ & $131.5 \mathrm{~d}$ & $5.23 \mathrm{ddd}(3.8,11.0,16.0)$ & $131.4 \mathrm{~d}$ \\
\hline $1^{\prime}$ & $136.6 \mathrm{~s}$ & & $135.9 \mathrm{~s}$ & & $135.8 \mathrm{~s}$ \\
\hline \multirow[t]{2}{*}{20} & $39.8 \mathrm{t}$ & $2.98 \mathrm{dd}(6.8,12.1)$ & $142.1 \mathrm{~d}$ & $6.48 \mathrm{~d}(11.7)$ & $142.0 \mathrm{~d}$ \\
\hline & & $3.23 \mathrm{dd}(11.0,12.1)$ & & & \\
\hline 21 & $171.8 \mathrm{~s}$ & & $149.3 \mathrm{~s}$ & & $149.2 \mathrm{~s}$ \\
\hline 1 & $170.1 \mathrm{~s}$ & & $170.1 \mathrm{~s}$ & & $170.7 \mathrm{~s}$ \\
\hline 17 & $205.4 \mathrm{~s}$ & & $211.7 \mathrm{~s}$ & & $211.9 \mathrm{~s}$ \\
\hline NH & & $6.69 \mathrm{br}$ & & $6.44 \mathrm{br}$ & \\
\hline $\mathrm{OH}$ & & & & $4.34 \mathrm{~s}$ & \\
\hline
\end{tabular}

a Coupling constants in $\mathrm{Hz}$.

$0.98 \mathrm{~Hz},{ }^{12)}$ and no nuclear Overhauser effect between them was observed in the NOE difference spectra. The carbonyl carbon at $\delta_{\mathrm{C}} 205.4$ in 1 shifted upfield in comparison with that $\delta_{\mathrm{C}}(211.7)$ in 2 , indicating the $\alpha, \beta$-double bond effect to the carbonyl carbon in the conjugated system. ${ }^{13}$

The chemical shifts of the remaining 23 carbons in $\mathbf{1}$, except for 6 carbons (C-17, $-18,-19,-20,-21$ and -23$)$ were approximately the same as those in $\mathbf{2}$.

On the basis of these results, the structure of 1 has been shown to be 6,7 -epoxy-10-phenyl-5,6,16,18-tetramethyl22-oxa-[12]-cyclochalas-13,19-diene-17,21-dione.

All signals of the ${ }^{1} \mathrm{H}$ - and ${ }^{13} \mathrm{C}$-NMR spectroscopic data for 1 and 2 were assigned by literature values ${ }^{6 \sim 14)}$ and by ${ }^{1} \mathrm{H}-\left\{{ }^{1} \mathrm{H}\right\}$ homo-spin decoupling experiments as shown in the table.

In a bioassay using lettuce seeds, 1 at a dose of $100 \mathrm{mg} / \mathrm{l}$ inhibited the germination by $50 \%$ after $24 \mathrm{hr}$. The root and hypocotyl growth were also inhibited by $70 \%$ and $60 \%$ at the same concentration, respectively.

Acknowledgments. We are indebted to Miss $\mathrm{K}$. Yamano for her technical assistance. This work was supported in part by a Grant-in-Aid for Special Project Research (No. 62107002) from the Ministry of Education, Science and Culture of Japan.

\section{References}

1) The Phytopathological Society of Japan, "Common Names of Economic Plant Diseases in Japan," Vols. I and III, Tokyo, 1975.

2) D. C. Aldridge, B. F. Burrows and W. B. Turner, J. Chem. Soc., Chem. Commun., 1972, 148; D. C. 
Aldridge, D. Greatbanks and W. B. Turner, ibid., 1973, 551.

3) S. B. Carter, Nature, 213, 261 (1967).

4) D. des S. Thomas, "Cytochalasins, Biochemical and Cell Biological Aspects," ed. by S. W. Tanenbaum, North-Holland Publ., Amsterdam, 1978, pp. 257 275.

5) K. Sawai, T. Okuno and T. Ito, Ann. Phytopath. Soc. Jpn., 48, 529 (1982).

6) R. J. Cole and R. H. Cox, "Handbook of Toxic Fungal Metabolites," Academic Press, New York, 1981, pp. 266 271.

7) K. Sawai, T. Okuno and T. Ito, Ann. Phyotopath. Soc. Jpn., 48, 529 (1982).

8) G. Büchi, Y. Kitaura, S. S. Yuan, H. E. Wright, J. Clardy, A. L. Demain, T. Glinsukon, N. Hunt and
G. N. Wogen, J. Am. Chem. Soc., 95, 5423 (1973).

9) A. I. Scott, "Interpretation of the Ultraviolet Spectra of Natural Products," Pergamon Press, Oxford, 1964, p. 55; M. Binder and C. Tamm, Helv. Chim. Acta, 56, 2387 (1973).

10) D. C. Aldridge, J. J. Armstrong, R. N. Speake and W. B. Turner, J. Chem. Soc. (C), 1967, 1667.

11) S. Murahashi, S. Nozakura, S. Fuji and K. Kikukawa, Bull. Chem. Soc. Jpn., 38, 1905 (1965).

12) A. W. Douglas and J. H. Goldstein, J. Mol. Spec., 16, 1 (1965).

13) J. B. Stothers, "Carbon-13 NMR Spectroscopy," Academic Press, New York, 1972, p. 284.

14) P. S. Steyn and F. R. van Heerden, J. Chem. Soc., Perkin Trans. 1, 1982, 541. 